\title{
PALAVRAS E LENTES: MEMÓRIAS DO CÁRCERE EM “VIDAS DO CARANDIRU” E "O PRISIONEIRO DA GRADE DE FERRO"
}

\author{
Gabriela Siqueira Lage*, Márcio Seligmann-Silva
}

\section{Resumo}

A pesquisa tem por objetivo, através da análise comparativa de duas obras: Vidas do Carandiru: histórias reais (2002) de Humberto Rodrigues e O prisioneiro da grade de ferro (auto retratos) (2003), do diretor Paulo Sacramento, compreender as diferentes formas que a memória e a experiência são trabalhadas no cinema e na literatura. Considerando, portanto, que se tratam de duas obras que retratam a experiência traumática do cárcere, pretende-se observar as produções que surgem desse contexto, levando em conta as particularidades das técnicas literária e cinematográfica e também buscando destacar os aspectos autobiográficos e testemunhais dos trabalhos analisados e as singularidades que daí advém.

\section{Palavras-chave: \\ Vidas do Carandiru; O prisioneiro da grade de ferro; testemunho.}

\section{Introdução}

Localizado na cidade de São Paulo, o Carandiru, até sua destruição em 2002, era o maior complexo prisional da América Latina, abrigando mais de 7.000 presos. Em 1992, o presídio chamou a atenção internacionalmente após o massacre de 111 presos, segundo os números oficiais , por parte da polícia durante a contenção de uma rebelião.

Tendo este cenário como pano de fundo, a obra Vidas do Carandiru: histórias reais (2002) de Humberto Rodrigues propõe-se a narrar o cotidiano da prisão através da perspectiva do autor, que foi preso injustamente e passou um ano e meio no cárcere.

Durante esse período, Rodrigues dedicou-se a registrar em um diário sua experiência, além de produzir crônicas e entrevistar seus companheiros em busca de suas histórias, material que posteriormente transformaria em um livro.

Filmado nesse mesmo complexo, o documentário $\mathrm{O}$ Prisioneiro da Grade de Ferro: auto retratos (2003), numa colaboração entre profissionais do cinema e os próprios detentos, mostra o cotidiano da prisão e as dificuldades vividas pelos presos no cumprimento de sua pena, num ambiente de violência, sofrimento e onde a sobrevivência é extremamente dura.

Ao colocar ambas as obras lado a lado, observa-se o mesmo esforço no sentido de testemunhar a respeito do cárcere de forma individualizada e, ao mesmo tempo, coletiva. A forma como esse testemunho se manifesta, no entanto, trará traços tanto de seus autores, da classe social de que proveem e dos privilégios ou prejuízos que isso lhes acarreta, e também do meio através do qual essas histórias são registradas: a literatura, por um lado, e o documentário, por outro. É a respeito da maneira como estes meios dialogam com o ato de testemunho e rememoração que o trabalho irá discorrer.

\section{Resultados e Discussão}

\section{Através da análise das obras, é possível} notar primeiramente $o$ alinhamento do relato de Rodrigues como parte de uma tendência literária brasileira que despontou por volta dos anos 2000 no que tange aos escritos que relatam a experiência do cárcere, que por sua vez se situa no plano mais geral do que se pode chamar de "literatura do real" (SELIGMANNSILVA, 2003). Pretendo compreender as implicações desse tipo de literatura.

A literatura de testemunho, principalmente na América Latina, carrega consigo não apenas a necessidade de testemunhar do sujeito, mas também um posicionamento político, que coloca esse sujeito narrador como representativo de uma classe social, que reivindica mudanças em relação à sua atual situação e vivência (SELIGMANN-SILVA, 2013).

Essa necessidade atrela a obra ao documentário de Sacramento, que, no entanto, opera em outro campo, do cinema, de forma que os instrumentos utilizados na construção desse testemunho e a maneira como ele se apresenta irão variar.

Enquanto Rodrigues segue a tendência da literatura de testimonio em colocar-se como narrador-representante que fala sobre a experiência do encarcerado, a obra de Sacramento em $O$ prisioneiro da grade de ferro traz consigo as diversas problemáticas do documentário e da representação, ao propor uma pluralidade de olhares por meio das filmagens feitas pelos próprios presos (FELDMAN, 2016). Enquanto ainda detém o poder de montagem do filme, o diretor se permite a inclusão do olhar do outro, transformando o filme num diálogo entre visões distintas, sem no entanto deixar de fazer proposições políticas claras, como ocorre na obra de Rodrigues.

\section{Conclusões}

Conclui-se, portanto, que as obras, cada uma em seu meio, apresentam narrativas que se aproximam do trauma e da violência, numa tentativa de representar situações limite por meio da arte e do testemunho. Essas representações irão aproximar-se quanto ao seu teor político e de memória, e distanciar-se quanto à técnica utilizada, que permite olhares distintos e coloca questões distintas.

FELDMAN, Ilana. "Um filme de": dinâmicas de inclusão do olhar do outro na cena documental. DEVIRES-Cinema e Humanidades, v. 9, n. 1, p. 50-65, 2016.

SELIGMANN-SILVA, Márcio. Violência, encarceramento, (in) justiça: Memórias de histórias reais das prisões paulistas. Revista de Letras, São Paulo, v. 43, n. 2, Memória e Literatura, p. 29-47, jul.-dez. 2003.

SELIGMANN-SILVA, Márcio. História memória e literatura: o testemunho na era das catástrofes. Campinas, SP: Editora Unicamp, 2013. 